\title{
ИССЛЕДОВАНИЕ ОСОБЕННОСТЕЙ ЛАНДШАФТА ШЕЛЬФА ЧЕРНОГО МОРЯ ГИДРОАКУСТИЧЕСКИМИ СРЕДСТВАМИ
}

\author{
А. П. Волощенко, П. П. Пивнев, Г. В. Солдатов \\ Южный федеральный университет, Россия \\ Поступила в редакцию 25 января 2019 г.
}

\begin{abstract}
Аннотация: В статье рассмотрена возможность применения гидроакустической техники для решения задач палеогеографии, геоморфологии и картографии. Рассмотрены результаты совместных экспедиций под эгидой Южного федерального университета и Русского географического общества в район мыса Панагия Таманского полуострова в 2015-2016 годах. Кратко описаны методика проведения работ и географические особенности района исследования. Представлены основные технические характеристики используемой гидроакустической аппаратуры - параметрического профилографа ПГЛ-101 и гидролокатора бокового обзора «Неман». Приведены данные сонарного профилирования и панорамного обзора морского дна прибрежной зоны мыса Панагия. Проведен краткий анализ полученных геологических и географических данных. Показана актуальность изучения тонкой структуры морского дна при помощи параметрического профилографа при ландшафтногеоморфологических реконструкциях участков Азово-Черноморского побережья.
\end{abstract}

Ключевые слова: Таманский полуостров, шельф, морское побережье, донные отложения, параметрический профилограф, гидролокатор бокового обзора, палеогеография, геоморфология, картография.

\section{Investigation of the landscape features of the shelf of the Black Sea by hydroacoustic means}

\section{A.P. Voloshchenko, P.P. Pivnev, G. V. Soldatov}

\begin{abstract}
The possibility of using hydroacoustic techniques for solving the problems of paleogeography, geomorphology and cartography is considered in the article. The results of joint expeditions under the auspices of the Southern Federal University and the Russian Geographical Society in the area of Cape Panagia of the Taman Peninsula in 2015-2016 are considered. The methodology of the work and the geographical features of the study area are briefly described. The main technical characteristics of the hydroacoustic equipment used - a parametric profilograph and a side-scan sonar -are presented. The data of sonar profiling and panoramic survey of the seabed of the coastal zone of Cape Panagia are presented. A brief analysis of the geological and geological data obtained is presented. The urgency of studying the fine structure of the seabed with the help of a parametric profilograph for landscape-geomorphological reconstructions of sections of the Azov-Black Sea coast is shown.
\end{abstract}

Key words: Taman Peninsula, shelf, seacoast, bottom sediment, parametric profilograph, side-scan sonar, paleogeography, geomorphology, cartography.

\section{ВВЕДЕНИЕ}

Вопросы палеогеографического развития Таманского полуострова за последние несколько тысяч лет привлекают внимание географов, геологов, археологов, историков. Особый интерес представляет динамика развития различных ком-

() Волощенко А.П., Пивнев П.П., Солдатов Г.В., 2019 понентов ландшафта побережья Азовского и Черного морей. Выяснение схем ландшафтного развития побережья Таманского полуострова необходимо как для подтверждения уже существующих теорий этнокультурного развития региона, так и для создания новых, при помощи ландшафтно-геоморфологических реконструкций отдельных участков Азово-Черноморского побережья [3, 4]. 
С эпохи плиоцена значительная часть Таманского полуострова была покрыта дельтой реки Кубань. Некоторые русла реки пролегали в депрессиях между антиклинальными поднятиями. Изменения дельты формировали облик региона. К примеру, расположение современных кубанских лиманов определяется именно дельтой древней реки. В трансгрессивные фазы определенная часть дельты затапливалась морем. В период позднего голоцена основным было черноморское русло реки Кубань, которое утратило свое значение лишь относительно недавно [2].

Дошедшие до нас письменные источники являются неполными. Поэтому появляются неоднозначности при проведении историко-географических реконструкций ландшафтно-геоморфологического облика Таманского полуострова. Причиной неоднозначности при определении места расположения древнегреческих колоний, палеотопонимов и палеогидронимов, известных из античной письменной традиции, боспорской эпиграфики и нумизматики [2].

Современный облик черноморского побережья Таманского полуострова является результатом тысячелетних воздействий колебаний уровня моря, береговой абразии, аллювиальных и тектонических процессов. К сожалению, эта особенность не учитывается множеством археологов и историков. В большинстве случаев исследователи переносят современные очертания полуострова в древность или же наоборот, информацию из античных источников привязывают к нынешним географическим ориентирам [2].

В настоящее время палеореконструкторы ищут новые критерии для определения местоположения древних поселений и городов, так как метод воссоздания береговой линии по 4-6-ти метровым изобатам недостаточно обоснован. Геологические данные свидетельствуют о наличии на этих уровнях реликтов с небольшим сдвигом относительно друг друга, одновременно нескольких древних береговых линий. Состояние древних береговых линий этого периода зачастую неудовлетворительное. Древняя береговая линия была значительно размыта в ходе трансгрессии, происходившей в последнее тысячелетие. В других районах черноморского побережья стремительное нарастание берега в последующий период стало причиной захоронения артефактов «фанагорийской» регрессии под массивом современных прибрежно-морских отложений [2].

Необходимо отметить, что исследования геоморфологического развития Таманского полуост- рова происходили в основном на суше или же в прибрежной зоне. Изучение строения и условий формирования донных отложений шельфов Азовского и Черного морей получило гораздо меньшее освещение в научной литературе. Данное упущение можно объяснить сложностью решаемой задачи и малой эффективностью или высокой стоимостью обычно применяемых при изучении методов и способов. К примеру, широко распространенная дешифровка результатов панхроматической аэрофотосъемки и спектрозональных космоснимков в данном случае практически неприменима. Сейсмоакустическое зондирование, в основном предназначенное для исследования сравнительно глубоких горизонтов, малоэффективно для изучения именно тонкой структуры осадочных слоев морского шельфа. Разведочное бурение скважин и непосредственное взятие проб довольно эффективный, но дорогостоящий метод. Отсутствие достаточного количества данных о морском шельфе Таманского полуострова затрудняет формирование общей картины геоморфологического развития региона. Такую информацию могут предоставить современные гидроакустические технологии, обеспечивающие детальное изучение поверхности и структуры дна $[5,6,10]$. К примеру, недавно была показана актуальность гидроакустических методов исследований подводных грязевых вулканов [7], оказывающих существенное влияния на ландшафт Таманского полуострова [2].

\section{АППАРАТУРА И МЕТОДИКА ПРОВЕДЕНИЯ ИССЛЕДОВАНИЯ}

В 2015 и 2016 годах в акватории Черного моря в прибрежной зоне мыса Панагия кафедра электрогидроакустической и медицинской техники института нанотехнологий, электроники и приборостроения Южного федерального университета (ЭГАиМТ ИНЭП ЮФУ) совместно с Русским географическим обществом (РГО) проводила археологические поиски объектов культурного наследия дистанционным гидроакустическим методом. Исследования проводились в районе с координатами $45.15^{\circ}$ с.ш., $36.61^{\circ}$ в.д. Одной из задач экспедиции было составление карты морского дна с учетом структуры осадочных слоев под уровнем дна. Было проведено сонарное профилирование прибрежной зоны мыса Панагия и панорамный обзор морского дна. Работы проводились в мелководном районе. От мыса более чем на 3 км на запад выступает риф Тутаева. Основная часть поверхности рифа располагается на глубинах от 0,5 до 1,5 м. Отдельные скальные выходы достигают поверхности 


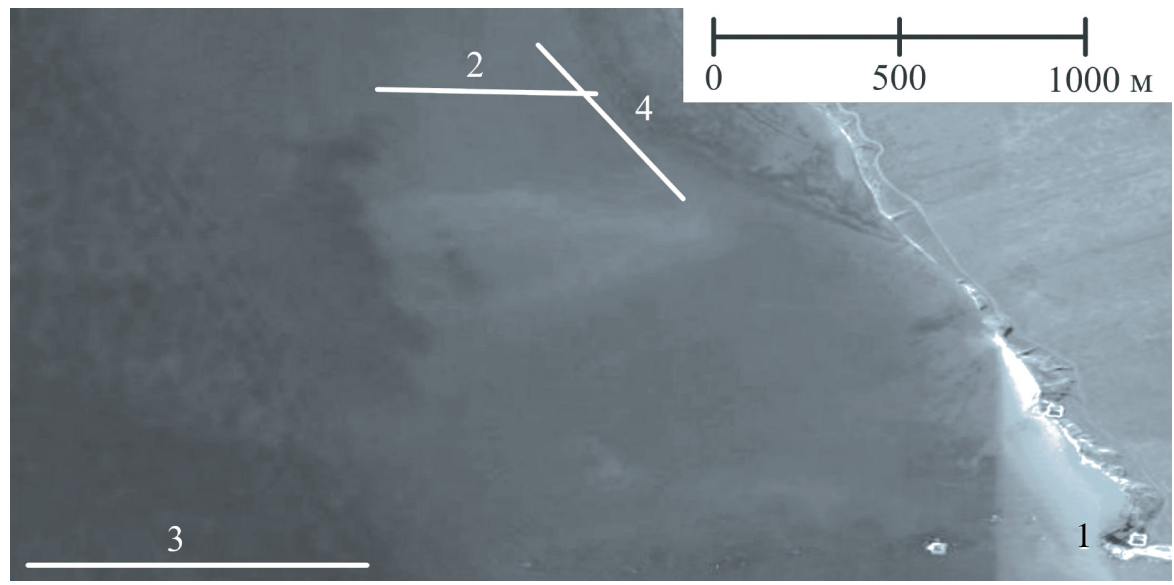

Puc. 1. Район работ экспедиции. 1 - мыс Панагия; 2 - траектория галса с рисунка 2; 3 - траектория галса с рисунка 3; 4 - траектория галса с рисунка 4

моря (во внутренней части рифа, примерно в 0,8 1,0 км от берега, где проходит 5-ти метровая изобата). Глубина в месте проведения работ колеблется от 0,5 до 10 м (рис. 1).

При проведении работ в этом районе применялись гидролокационные системы с параметрическими излучающими антеннами. Панорамная съемка поверхности дна производилась гидролокатором бокового обзора (ГБО). Работы велись дистанционным методом, основанном на излучении в водную среду в сторону морского дна и приеме акустических сигналов. Аппаратура, используемая для работ, размещалась на плавсредстве малого водоизмещения, где были закреплены гидроакустические антенны, ориентированные в сторону дна. Используемые принципы акустической локации не наносят экологического или иного вреда окружающей среде. Плавсредство с установленной на нем аппаратурой, в состав которой входит параметрический профилограф (ППФ) и ГБО, проходило галсами заданные районы со скоростью 3 5 узлов. При этом измерялись параметры эхо-сигналов от морского дна и координаты плавсредства. Комплексирование ППФ и ГБО необходимо для уменьшения количества профилей в районе работ. По данным ГБО можно судить о типе грунта и об изменчивости его структуры в стороне от профиля.

В результате исследований была получена своеобразная карта морского дна в виде панорамы поверхности дна и вертикальных разрезов донного грунта. Полученные результаты позволяют оценить структуру, тип, состав донных осадков и определить их вертикальную и горизонтальную изменчивость.

Для профилирования дна и донных осадков использовался ППФ ПГЛ-101, разработанный и изготовленный предприятием ООО «НЕЛАКС» совместно с кафедрой ЭГАиМТ ИНЭП ЮФУ. Для площадной съемки использовался ГБО серии «Неман» $[1,9]$, который является результатом многолетней совместной работы инженеров и ученых ООО «НЕЛАКС» и АО «НИИП имени В. В. Тихомирова».

\section{АНАЛИЗ РЕЗУЛЬТАТОВ}

Рассмотрим результаты зондирования, характеризующие особенности рельефа морского дна и верхней толщи осадочных слоев в районе работ. В ходе проведенных исследований в морском дне было обнаружено множество пластов моноклинально-залегающих осадочных пород. Оценка уровня коэффициента отражения и анализ проб грунта, взятых вблизи берега, позволяют предположить, что слои состоят из песка и голубой глины. Все слои имеют характерный пологий наклон в сторону берега.

На рисунке 2 приведен типовой профиль донных осадочных структур в прибрежной части мыса Панагия. На эхограмме видны слои, образуемые пластами голубой глины. Движение судна происходило в сторону удаления от берега. В районе рифа, осадочные слои прорваны твердыми породами. На рисунке 3 приведена профилограмма галса параллельного рифу Тутаева, на котором видно, что глубины между пиками твердой породы засыпаны песком.

Согласно результатам анализа космоснимков, в 1,5 км на северо-запад от мыса Панагия расположен выход твердой породы, скрытый поверхностью моря. Выход твердой породы сверху по форме напоминает полукруг, удаленный на 300 м от берега и упирающийся концами в него. Анализ 


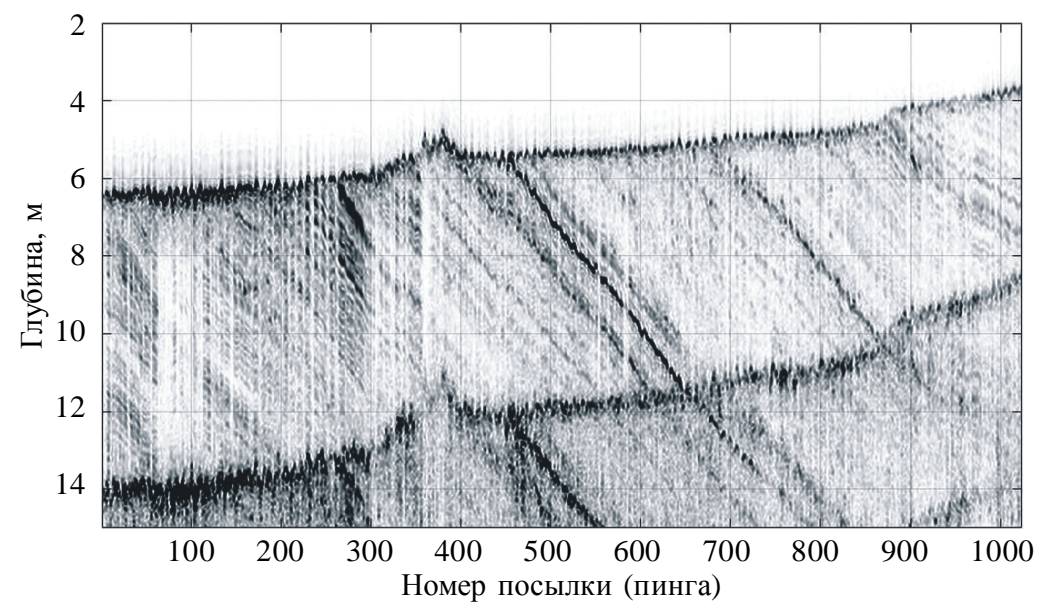

Pис. 2. Акустическая запись ППФ участка морского дна, $\left(45.15^{\circ}\right.$ с.ш., $36.62^{\circ}$ в.д.)

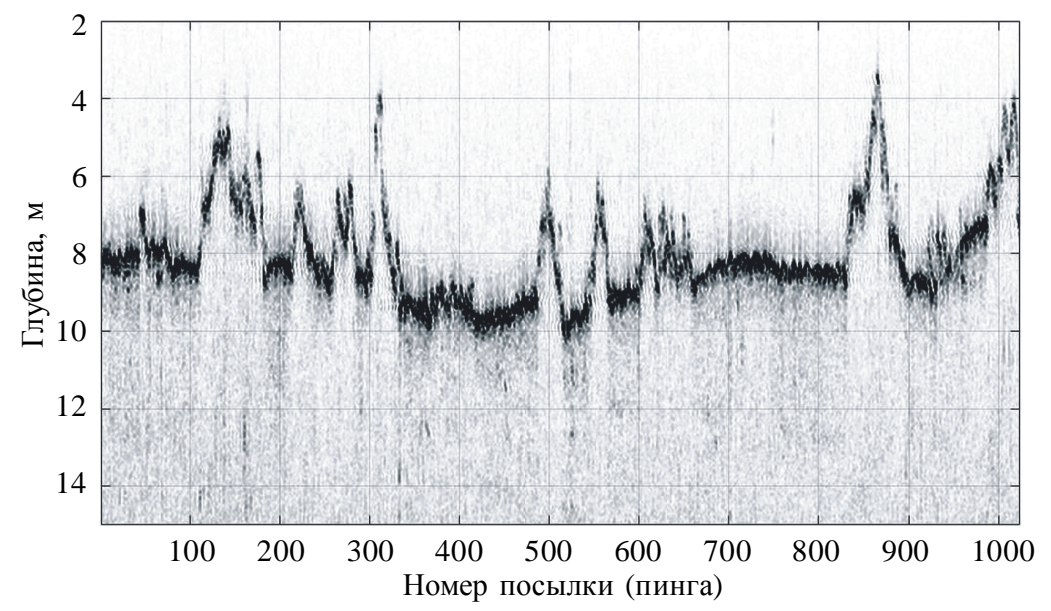

Puc. 3. Акустическая запись ППФ участка морского дна, параллельного рифу Тутаева, (45.14º.ш., $36.61^{\circ}$ в.д.)

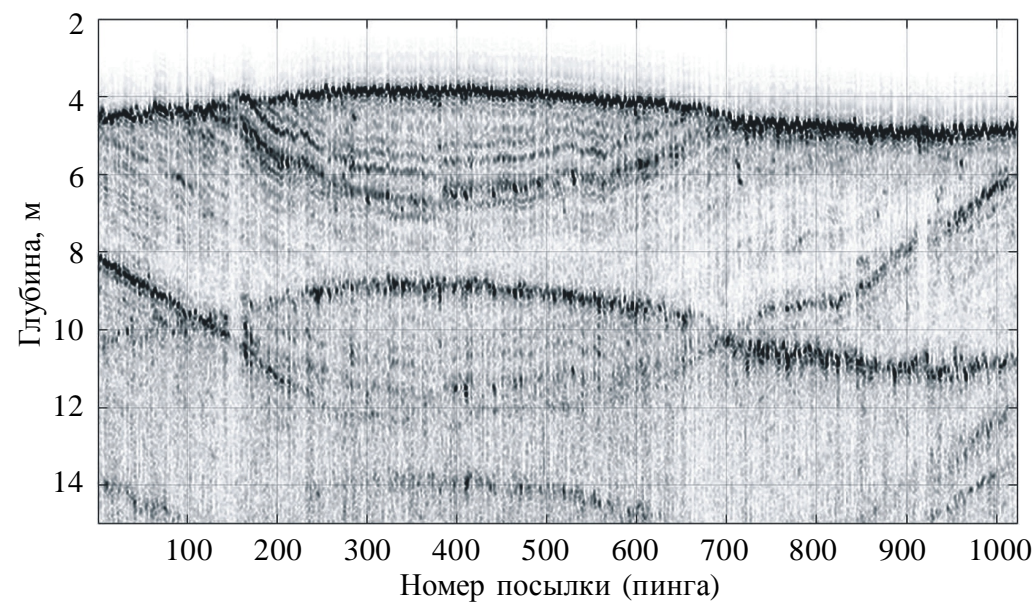

Рис. 4. Профилограмма участка морского дна с «ямой», $\left(45.15^{\circ}\right.$ с.ш., $36.62^{\circ}$ в.д. $)$ 


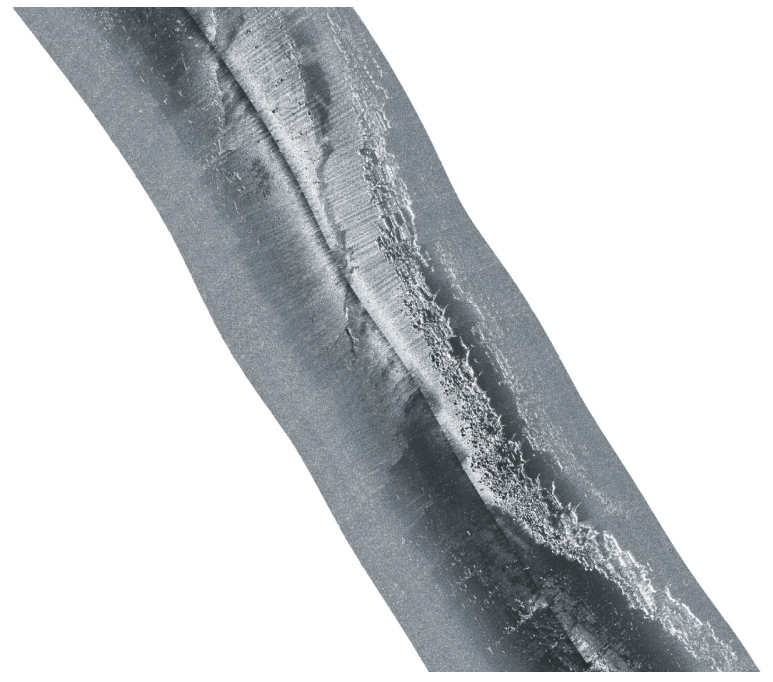

Рис. 5. Мозаика участка морского дна (45.15․․, $36.62^{\circ}$ в.д.)

галса, пройденного параллельно берегу, показывает, что данное явление оказывает влияние на форму залегания осадочных слоев. Из записи профилограммы на рисунке 4 видно, что расположение слоев имеет синклинальный характер.

Дополнительную информацию для интерпретации и уточнения отмеченных выше особенностей рельефа можно получить, анализируя акустические изображения морского дна, полученные с помощью ГБО. На рисунке 5 показана эхограмма района дна, соответствующая профилограмме на рисунке 4. Данные представлены в виде фрагмента карты морского дна. На рисунке 5 отчетливо виден выход коренных пород.

Приступая к выполнению работы, современная экспедиция располагала картой района поиска с обнаруженными объектами культурного наследия в экспедициях 80-х годов. Координаты объектов определялись с помощью теодолитных постов с привязкой к вехам. Современные экспедиции осуществляли поиск объектов с помощью GPS. В результате обследования дна в районе точек на карте обнаружить искомые объекты не удалось. Из этого можно сделать вывод, что координаты находок по карте 1983 года определены с большой погрешностью. Наиболее вероятно, что погрешность обусловлена систематической погрешностью, вследствие ошибки при привязке координат теодолитных постов.

Применение гидроакустических приборов позволяет определить величину систематической погрешности и существенно увеличить скорость поиска. Полоса обзора морского дна ГБО составляла около 100 м. Для того, чтобы определить си-

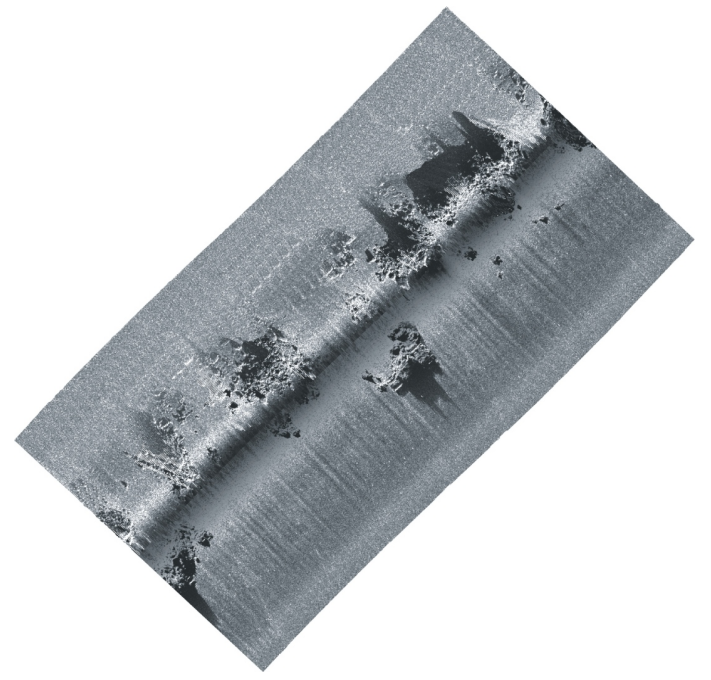

Рис. 6. Эхограмма ГБО участка морского дна (45.15ㄷ.ш., $36.60^{\circ}$ в.д.)

стематическую погрешность нужно найти объекты, отмеченные на карте 1983 года и сравнить координаты на карте с показаниями GPS. Разность координат и будет представлять собой систематическую погрешность.

В качестве объектов, по которым определялась поправка, были выбраны одиночные развалы подводных камней на плоском морском дне. Подобные объекты были выбраны ввиду простоты поисковых работ, проводимых с помощью ГБО. На рисунке 6 приведена акустическая запись ГБО исследуемого района.

Анализируя акустическую запись на рисунке 6 , можно увидеть развал камней, расположенный прямо под дном судна. На рисунках 7 (современная карта) и 8(карта 1983 г.) траектория галса выложена на имеющиеся карты. Сопоставляя акустические записи с картами, можно сделать вывод, что на карте 1983 года подводные камни смещены на северо-восток на расстояние около 125 м. Подобные результаты были получены при сопоставлении акустической записи с картами на рисунках 7-8.

Из вышесказанного можно сделать вывод, что искать объекты культурного наследия нужно в направлении на юго-восток на расстоянии около 100150 м от координат, приведенных на карте 1983 года.

Таким образом, сузить круг поиска можно, используя ГБО. Для этого нужно найти подводные камни, отмеченные на карте. По карте находок 1983 года скорректировать координаты объектов поиска относительно координат, найденных ГБО камней. Только после этого следует детально ис- 


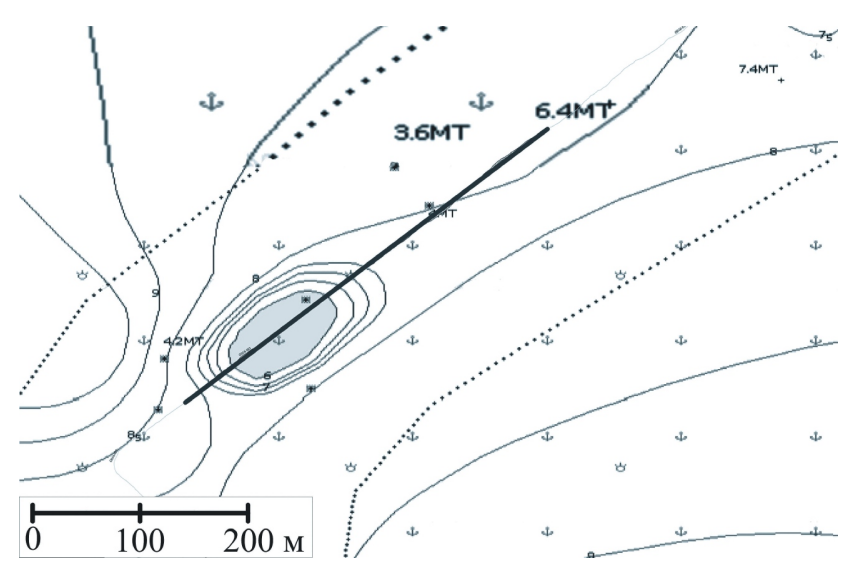

Pис. 7. Траектория галса с рисунка 6 на современной карте

следовать район предполагаемого расположения интересующих объектов.

\section{ЗАКЛЮЧЕНИЕ}

Гидролокационные методы дистанционного зондирования морского дна являются основой для измерения морфометрии рельефа и получения данных о структуре донных отложений морского дна. Полученная в ходе экспедиций информация, может быть использована для создания единой геоакустической модели [8] Таманского полуострова, которая аккумулирует имеющиеся геологические, геофизические, гидрологические и петрофизические данные о регионе. Результаты исследований будут интересны при решении задач геоморфологии и палеогеографии для изучения изменений и реконструкции геологического облика Таманского полуострова в прошлом. Неполнота сохранившихся письменных источников порождает неоднозначные историко-географические реконструкции ландшафтно-геоморфологического облика Таманского полуострова [2]. Полученные новые материалы позволяют оценить произошедшие изменения в облике данного участка побережья и восполнить существующие пробелы.

Картографирование внутренних водоемов и прибрежных шельфовых областей России по большей части не носят регулярного характера, что объясняется главным образом отсутствием отечественных технических средств, не уступающих зарубежным образцам. Полевые испытания гидроакустического комплекса, состоящего из ГБО серии «Неман» и ППФ ПГЛ-101, показали, что оборудование успешно выполняет задачи сонарного профилирования и панорамного обзора морского дна. В результате была получена карта поверхности морского дна района работ с учетом структуры осадочных слоев под дном.

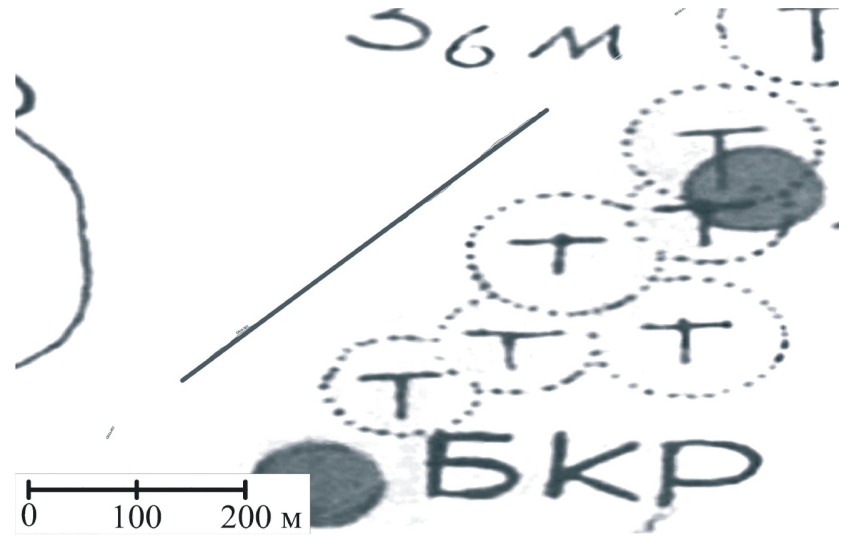

Puc. 8. Траектория галса с рисунка 6 на карте 1983 г.

\section{СПИСОК ЛИТЕРАТУРЫ}

1. Гидроакустические системы дистанционного зондирования дна водоемов и водной толщи / А. И. Демидов [и др.] // IV Всероссийская конференция «Радиолокация и радиосвязь» : сборник докладов. - Москва, 2010. - С. 63-67.

2. Горлов Ю. В. Географическая ситуация на Таманском полуострове во второй половине голоцена / Ю. В. Горлов // Проблемы истории, филологии, культуры. - 2008. - № 21. - С. 415-437.

3. Евсюков Ю. Д. Рельефообразующие факторы преобразования материковой окраины вблизи Геленджика / Ю. Д. Евсюков, В. И. Руднев // Известия Российской академии наук. Серия географическая. - 2016. № 3. - С. 97-109.

4. Изменения ландшафтно-климатических условий Таманского полуострова на протяжении последних 6000 лет / Н. С. Болиховская [и др.] // Проблемы истории, филологии, культуры. - 2002. - № 12. - С. 257-271.

5. Дмитревский Н. Н. Использование сейсмоакустического комплекса для исследований верхней осадочной толщи и рельефа морского дна в Восточной Арктике / Н. Н. Дмитревский [и др.] // Океанология. - 2013. - Т. 53, № 3. - С. 412-417.

6. Колосков Е. Н. Применение современных гидрографических технологий для изучения рельефа и донного газопроявления в северных морях России / Е. Н. Колосков, Ю. Г. Фирсов // Вестник государственного университета морского и речного флота им. адмирала С. О. Макарова. - 2015. - № 3 (31). - С. 54-62.

7. Подводные грязевые вулканы Таманского полуострова (по данным гидролокационных исследований) / В. И. Каевицер [и др.] // Вулканология и сейсмология. - 2016. - № 4. - С. 27-33.

8. Свининников А. И. Геоакустическая модель шельфа Японского моря (на примере залива Посьета) / А. И. Свининников, И. О. Ярощук // Вестник Дальневосточного отделения Российской академии наук. 2006. - № 3. - C. 85-93. 
9. Скнаря А. В. Отечественные гидролокаторы со сложными сигналами производства НИИ приборостроения имени В.В. Тихомирова / А. В. Скнаря, Е. В. Тутынин, М. А. Климов // Морской сборник. - 2011. Т. 1968, № 3. - С. 47-51.

10. Солдатов Г. В. Определение параметров донных осадков дистанционными методами в целях экологического мониторинга / Г. В. Солдатов // Известия ЮФУ. Технические науки. - 2011. - № 9 (122). - С. 88-93.

\section{REFERENCES}

1. Gidroakusticheskie sistemy distantsionnogo zondirovaniya dna vodoemov i vodnoy tolshchi / A. I. Demidov [i dr.] // IV Vserossiyskaya konferentsiya «Radiolokatsiya i radiosvyaz'» : sbornik dokladov. - Moskva, 2010. S. 63-67.

2. Gorlov Yu. V. Geograficheskaya situatsiya na Tamanskom poluostrove vo vtoroy polovine golotsena / Yu. V. Gorlov// Problemy istorii, filologii, kul'tury. - 2008. - № 21. - S. 415-437.

3. Evsyukov Yu. D. Rel'efoobrazuyushchie faktory preobrazovaniya materikovoy okrainy vblizi Gelendzhika / Yu. D. Evsyukov, V. I. Rudnev // Izvestiya Rossiyskoy akademii nauk. Seriya geograficheskaya. - 2016. - № 3. S. 97-109.

4. Izmeneniya landshaftno-klimaticheskikh usloviy Tamanskogo poluostrova na protyazhenii poslednikh 6000 let / N. S. Bolikhovskaya [i dr.] // Problemy istorii, filologii, kul'tury. - 2002. - № 12. - S. 257-271.

Волощенко Александр Петрович

кандидат технических наук, доцент Института нанотехнологий, электроники и приборостроения Южного федерального университета, г. Таганрог, т. 8-(863)-468-18-90, E-mail: apvoloshhenko@sfedu.ru

Пивнев Петр Петрович

кандидат технических наук, доцент Института нанотехнологий, электроники и приборостроения Южного федерального университета, г. Таганрог, т. 8-(863)-468-18-90, E-mail:pivnevpp@sfedu.ru

Солдатов Геннадий Валерьевич

ассистент Института нанотехнологий, электроники и приборостроения Южного федерального университета, г. Таганрог, т. 8-(863)-437-17-95, E-mail: gsoldatov@sfedu.ru
5. Dmitrevskiy N. N. Ispol'zovanie seysmoakusticheskogo kompleksa dlya issledovaniy verkhney osadochnoy tolshchi i rel'efa morskogo dna v Vostochnoy Arktike / N. N. Dmitrevskiy [i dr.] // Okeanologiya. - 2013. T. 53, № 3. - S. 412-417.

6. Koloskov E. N. Primenenie sovremennykh gidrograficheskikh tekhnologiy dlya izucheniya rel'efa i donnogo gazoproyavleniya v severnykh moryakh Rossii / E. N. Koloskov, Yu. G. Firsov // Vestnik gosudarstvennogo universiteta morskogo i rechnogo flota im. admirala S. O. Makarova. - 2015. - № 3 (31). - S. 54-62.

7. Podvodnye gryazevye vulkany Tamanskogo poluostrova (po dannym gidrolokatsionnykh issledovaniy) / V. I. Kaevitser [i dr.] // Vulkanologiya i seysmologiya. 2016. - № 4. - S. 27-33.

8. Svininnikov A. I. Geoakusticheskaya model' shel'fa Yaponskogo morya (na primere zaliva Pos'eta) / A. I. Svininnikov, I. O. Yaroshchuk // Vestnik Dal'nevostochnogo otdeleniya Rossiyskoy akademii nauk. - 2006. - № 3. S. 85-93.

9. Sknarya A. V. Otechestvennye gidrolokatory so slozhnymi signalami proizvodstva NII priborostroeniya imeni V.V. Tikhomirova / A. V. Sknarya, E. V. Tutynin, M. A. Klimov // Morskoy sbornik. - 2011. - T. 1968, № 3. - S. 47-51.

10. Soldatov G. V. Opredelenie parametrov donnykh osadkov distantsionnymi metodami $\mathrm{v}$ tselyakh ekologicheskogo monitoringa / G. V. Soldatov // Izvestiya YuFU. Tekhnicheskie nauki. - 2011. - № 9 (122). - S. 88-93.

Voloshchenko Alexander Petrovich

Candidate of Technical Sciences, Associate Professor of the Institute of Nanotechnologies, Electronics and Equipment Engineering, Southern Federal University, Taganrog, tel. 8-(863)-468-18-90, E-mail: apvoloshhenko@sfedu.ru

\section{Pivnev Peter Petrovich}

Candidate of Technical Sciences, Associate Professor of the Institute of Nanotechnologies, Electronics and Equipment Engineering, Southern Federal University, Taganrog, tel. 8-(863)-468-18-90, E-mail: pivnevpp@ sfedu.ru

Soldatov Gennady Valeryevich Assistant of the Institute of Nanotechnologies, Electronics and Equipment Engineering, Southern Federal University, Taganrog, tel. 8-(863)-437-17-95, E-mail: gsoldatov@sfedu.ru 